\title{
Recruiting a Diverse Workforce for Academic/Research Librarianship: Career Decisions of Subject Specialists and Librarians of Color
}

\author{
Kyung-Sun Kim, Ming-Hsin Chiu, Sei-Ching Joanna \\ Sin, and Louise Robbins
}

In libraries and other related organizations, information professionals with subject and cultural/ language expertise are invaluable as they can contribute to the provision of better service for users who are becoming increasingly diverse. Recent statistics indicate that there is a great need to recruit more librarians with subject specialties and with diverse ethnic/cultural backgrounds, especially in academic libraries. Two separate studies were conducted to examine career decisions of such individuals who are already working, or likely to work, in academic libraries. Suggestions are made to develop effective recruitment strategies and to ensure that the supply of the two special groups of the library profession will effectively meet the demand.

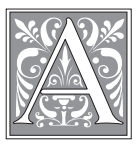

cademic and research libraries play an important role in the advancement of higher education by organizing and disseminating information that facilitates scholarly communication and research. Librarians in such organizations are key assets as they are the ones who provide information services to the research community.

The changing demographics of librarianship and the nation, however, have raised some concerns and called for a more proactive effort in recruiting librarians. According to Curran, by the year of 2010, more than 83,000 librarians in North America will have reached the age of 65, and their retirements will result in a severe shortage in the profession. ${ }^{1}$ Tracking the aging trend of research librarians, Wilder substantiates the gap between the numbers of retirements and new recruits to the profession, indicating a great need for aggressive recruitment. ${ }^{2}$

In addition to the looming shortage of librarians as current professionals retire, there seems to be a shortage of certain kinds of expertise among the graduates of the American Library Association (ALA) accredited master's degree programs.

Kyung-Sun Kim is Associate Professor, Ming-Hsin Chiu and Sei-Ching Joanna Sin are doctoral students, and Louise Robbins is Director E Professor in the School of Library and Information Studies at the University of Wisconsin-Madison; e-mail:kskim@slis.wisc.edu, minghsinchiu@wisc.edu, sjsin@wisc.edu, and lsrobbin@wisc.edu, respectively. The authors gratefully acknowledge the support of the American Library Association (ALA) and the Institute of Museum and Library Services (IMLS). 
Lynch reports that 23.1 percent of vacancies in medium and large public libraries and college and university libraries result from a shortage of qualified people with a particular specialty, such as those subject specialists with specialized knowledge in certain subject areas and/or languages. ${ }^{3}$ Another concern is the gap in the proportion of people of color between the librarian and the U.S. populations. The ethnic minority population constitutes over 30 percent of the U.S. population and is projected to reach 47 percent in $2050 .{ }^{4}$ In the LIS field, however, minority groups constitute only 10 to 12 percent of the LIS student and librarian populations. Despite continual efforts by LIS schools and associations in recruiting and retaining students of color, the proportions of ethnic minorities in LIS student and librarian populations remain significantly lower than in the U.S. population, and the gap has not narrowed by much. Berry points out that the challenge of the library profession is clearly about recruitment, but it is also about recruiting a "diverse workforce. ${ }^{5}$ As demographic indicators point to more culturally and ethnically diverse communities, libraries need to recruit more diverse professional staff. ${ }^{6}$ In response to such needs, the Focus on the Future Task Force of the Association of College and Research Libraries (ACRL), in consultation with other academic library associations, has identified "recruitment, education, and retention of librarians" as one of the top issues facing academic libraries.?

To develop effective strategies for recruiting individuals into a profession, it is critically important to understand the individuals who are likely to enter the profession or those currently in the profession, as the two groups share similar characteristics and preferences. ${ }^{8}$ In an effort to increase this understanding, two nationwide studies were conducted to identify ways to address the shortage of subject specialists and ethnic minorities in academic librarianship. The first study aimed at identifying characteristics of LIS students with advanced degrees in other fields, who are likely to become subject specialists in academic and research libraries; their projected and actual career path; and also factors that attracted them to choose librarianship. Turning to ethnic minorities, the second study aimed at understanding how and when librarians of color choose the LIS field; what types of libraries they prefer; and what recruitment strategies they think are effective. The goal of this paper is to contribute to the better recruitment of a diverse population in LIS education and academic libraries.

\section{Literature Review \\ Need for Subject Specialists}

Subject specialists in libraries are defined as individuals with possession of sufficient experience/education in a particular discipline in addition to knowledge of librarianship. ${ }^{9}$ Qualifications required for the subject specialist positions often include advanced degrees in a subject area, in addition to an ALA-accredited MLS degree. ${ }^{10}$ The need for an additional advanced degree seems important for those working as subject specialists.

White suggests that subject specialists are often given responsibilities of specialized reference and collection development and serve as the library's appointed liaison with teaching faculty because they share similar academic background and experience with faculty. ${ }^{11}$ To perform these or other related services effectively, a subject specialist must have "a detailed and intimate knowledge of the needs of his total clientele, the bibliographical organization and problems of his field, and a thorough understanding of library operations, including the limitations as well as the special capabilities they provide."12 It is this mixture of subject knowledge and knowledge of the user community that allows the subject librarian to mediate effectively between available resources and the user. ${ }^{13}$

In the literature on subject specialists, researchers and practitioners confirm 
several benefits that subject specialists have brought to the LIS field and user communities. The tacit knowledge and familiarity of a subject area allow subject specialists to carry out a task efficiently. Their subject specialties are a definite advantage in coping with changes, and this has been especially evident in the academic library's adjustment to the increasing demands for user-oriented services. $^{14}$

\section{Need for Librarians of Color}

Because the United States is becoming increasingly diverse ethnically and culturally, the persistent under-representation of librarians of color is an issue of concern. To improve services to ethnic minorities and to recruit and retain librarians of color, the ALA issued a special report, Equity at Issue: Library Services to the Nation's Four Major Minority Groups, and outlined action recommendations. In the '80s, only about 10 percent of the academic librarians and 12 percent of the public librarians were from the four major ethnic groups, including African American, Asian American, Hispanic, and Native American. ${ }^{15}$ Over the years, there has been some improvement: in 1998, for example, librarians of color constituted 13.2 percent of academic librarian and 13.4 percent of public librarian populations. ${ }^{16}$ However, a recent report reveals that the ratio of librarians of color among credentialed librarians had actually dropped from 12 percent in 1990 to 10 percent in $2000 .{ }^{17}$ The U.S. population projections indicate that, by 2050, the four minority groups will represent almost half of the U.S. population. ${ }^{18}$ As E. J. Josey and others warned, without systematic recruitment efforts, the gap between LIS and US populations may widen even further; and the librarian population will not reflect the users that librarians serve. ${ }^{19}$

Studies suggest that interpersonal similarities (such as similarity in ethnicity or culture), increase ease of communication, foster relationships of trust and reciprocity, and encourage a sense of belonging and membership. ${ }^{20}$ As in schools and other public organizations, it is important to have enough professionals/staff of color in libraries; because it helps all users, regardless of their ethnicity, see authority figures looking like them and feel comfortable and welcome. In institutes of higher education, about 29 percent of the students are minorities, ${ }^{21}$ and about 4 percent are international students. ${ }^{22} \mathrm{An}$ ethnically and culturally diverse workforce in academic libraries will facilitate the interaction with these diverse user groups and help reduce the level of library anxiety felt by users. ${ }^{23}$ Equipped with language and cultural knowledge, librarians of color will also be able to provide effective services in different areas including reference, cataloging, and collection development. ${ }^{24}$ Academic libraries are a visible and primary point of multicultural intersection in the academia. ${ }^{25}$ Increasing the representation of librarians of color is one of the crucial steps toward a more pluralistic and equitable society that fosters learning.

\section{Recruitment Efforts}

Recruiting a diverse workforce into librarianship is an important matter to LIS schools as well as libraries. As the professional librarian position requires an MLIS degree from an ALA-accredited program, such recruitment effort should start with individuals who might be interested in pursuing LIS studies. Efforts have been made to identify factors related to recruitment, and research has revealed that role models, time required to complete an LIS degree, marketplace outlook and career options, and appreciation of information and knowledge fields are among the factors important to recruitment. ${ }^{26}$ In addition to these factors, researchers have also tried to identify effective strategies for recruitment. Kaufman suggests techniques such as utilizing listservs and making required qualifications flexible and open, ${ }^{27}$ and Perry recommends using outreach and positive image strategies to expand the pool of potential students. ${ }^{28}$ 
Libraries, LIS schools, and associations have implemented various initiatives to recruit subject specialists and ethnic minorities. The Council on Library and Information Resources (CLIR), for example, offers the equivalent of an apprenticeship postdoctoral program to encourage humanities $\mathrm{PhDs}$ to go into academic librarianship. The Mellon Foundation funds postdoctoral fellowship opportunities in research librarianship for recent graduates of area studies. ${ }^{29}$ The Association of Research Libraries (ARL) has formed a Task Force on Special Collections to provide hands-on experience for recent PhDs in managing primary research materials, in response to the needs of national and international scholarship. ${ }^{30}$ With regard to ethnic diversity, the ALA created the Spectrum Initiative to promote diversity in the library community and recruit minority librarians by providing scholarships, mentoring, and training programs. A number of LIS schools, as well as libraries, have shown their support of the Spectrum scholarship program by agreeing to make additional financial commitments, such as matching grants. ${ }^{31}$ Furthermore, many academic libraries also offer residency programs for underrepresented groups, which have been fairly successful. ${ }^{32}$ The ARL sponsors the Leadership and Career Development Program for librarians of color who have demonstrated leadership in research libraries, and launched Initiative to Recruit a Diverse Workforce to recruit LIS graduate students of color to ARL libraries upon graduation. ${ }^{33}$

To support these continuous efforts to recruit a diverse workforce into the LIS profession, more empirical research on LIS recruitment is needed. Many have contributed to the discussion by suggesting recruitment strategies and initiatives. ${ }^{34}$ Others carried out studies to better understand the demographic trends in the profession and the recruitment efforts currently employed by various academic libraries. ${ }^{35}$ What is also needed is research that compares and identifies effective recruitment strategies based on the recruit's point of view. As recruitment initiatives require a significant amount of time, efforts, and resources, such studies will be helpful for the LIS schools and libraries to plan and evaluate their recruitment initiatives, and also to allocate resources efficiently.

\section{Methodology}

Web-based surveys were used in both studies. To develop a survey questionnaire in the first study (hereafter referred to as Study 1), existing literature on library personnel management, career decisions, and subject specialists was consulted. The questionnaire was finalized based on the results of a pilot test conducted with ten advanced degree holders enrolled in an LIS program. For the second study (hereafter referred to as Study 2), a questionnaire was developed through a review of extant literature related to career decisions, recruitment, and retention of students, including students of color, in different fields. It was finalized based on the results of a pilot test with five librarians of color, and also the feedback from members of the advisory board, consisting of ten librarians and faculty of color in the LIS field. To make the surveys available through the Web, Zoomerang and PHPSurveyor were used for Study 1 and Study 2, respectively.

Study 1 collected data from LIS students with advanced degrees in fields other than LIS. The deans/directors of the fifty-six ALA-accredited LIS education programs were contacted. They were asked to help distribute a cover letter with the Web survey link through their students' listservs and to encourage their students who had already received or were concurrently pursuing an advanced degree in other fields to participate in the study. The questionnaire consisted of thirteen questions, with focus on the participants' academic background, their actual or projected career paths, factors that attracted them to the LIS field, and factors that influenced them to undertake the LIS degree program. Data were collected from January through May 2005. 


\begin{tabular}{|l|c|c|}
\hline \multicolumn{3}{|c|}{$\begin{array}{c}\text { TABLE 1 } \\
\text { Study 1: Subject Specialists } \\
\text { Preferred Types of Library }(n=326)\end{array}$} \\
\hline \hline \multicolumn{1}{|c|}{ Type of Library } & Number & Percentage \\
\hline $\begin{array}{l}\text { Academic and Research } \\
\text { Library }\end{array}$ & 175 & $53.7 \%$ \\
\hline School Library & 41 & $12.6 \%$ \\
\hline Public Library & 36 & $11.1 \%$ \\
\hline $\begin{array}{l}\text { Special Library/Corporate } \\
\text { Information Center }\end{array}$ & 35 & $10.7 \%$ \\
\hline Archive & 31 & $9.5 \%$ \\
\hline Government Library & 4 & $1.2 \%$ \\
\hline $\begin{array}{l}\text { Information Service/ } \\
\text { Access Provider }\end{array}$ & 2 & $0.6 \%$ \\
\hline Historical Society & 1 & $0.3 \%$ \\
\hline $\begin{array}{l}\text { Freelance Information } \\
\text { Professional }\end{array}$ & 1 & $0.3 \%$ \\
\hline Total & 326 & $100.0 \%$ \\
\hline
\end{tabular}

forma (National Association to Promote Library and Information Services to Latinos and the Spanish-Speaking), and other ALA-affiliated groups. The questionnaire consisted of thirty-two questions focusing on participants' background, their experience with LIS schools and associations, and their suggestions on recruitment/retention. The data were collected from November 2004 through March 2005.

\section{Results and Discussion}

A total of 326 LIS students from sixteen ALA-accredited LIS programs participated in Study 1. All of the participants were either advanced degree holders or working on an advanced degree program in other fields. A

Study 2 surveyed librarians of color who graduated from an ALA-accredited LIS program or those currently enrolled in such a program. To introduce the study and also to encourage librarians of color to participate, an announcement was posted to listservs of the American Indian Library Association, Asian/Pacific American Librarians Association, Black Caucus of the American Library Association, Chinese American Librarians Association, Re- total of 182 librarians of color participated in Study 2. Most of the participants (85\%) had already graduated from an ALA-accredited LIS program, while the rest were currently enrolled in such a program.

\section{Academic/Research Librarianship}

To discover the advanced degree holders' career paths, Study 1 asked the participants to identify the type of libraries in which they were most interested. Table

\begin{tabular}{|l|c|c|c|c|c|c|}
\hline \multicolumn{7}{|c|}{ TABLE 2 } \\
Education Level and Preferred Types of Library $(\mathbf{n}=\mathbf{2 9 5})$ \\
\hline & \multicolumn{2}{|c|}{ Master } & \multicolumn{2}{c|}{ Doctoral } & \multicolumn{2}{c|}{ Total } \\
\hline Type of Library & Counts & $\begin{array}{c}\% \text { of } \\
\text { Column }\end{array}$ & Counts & $\begin{array}{c}\text { \% of } \\
\text { Column }\end{array}$ & Counts & $\begin{array}{c}\text { \% of } \\
\text { Column }\end{array}$ \\
\hline $\begin{array}{l}\text { Academic/Research } \\
\text { and Archives }\end{array}$ & 147 & $61.2 \%$ & 38 & $69.1 \%$ & 185 & $62.7 \%$ \\
\hline $\begin{array}{l}\text { Public, School, } \\
\text { and Special }\end{array}$ & 71 & $29.6 \%$ & 8 & $14.5 \%$ & 79 & $26.8 \%$ \\
\hline Others & 22 & $9.2 \%$ & 9 & $16.4 \%$ & 31 & $10.5 \%$ \\
\hline Total & 240 & $100.0 \%$ & 55 & $100.0 \%$ & 295 & $100.0 \%$ \\
\hline * Out of 326 participants, 295 of them responded to this answer. & & \\
\hline
\end{tabular}




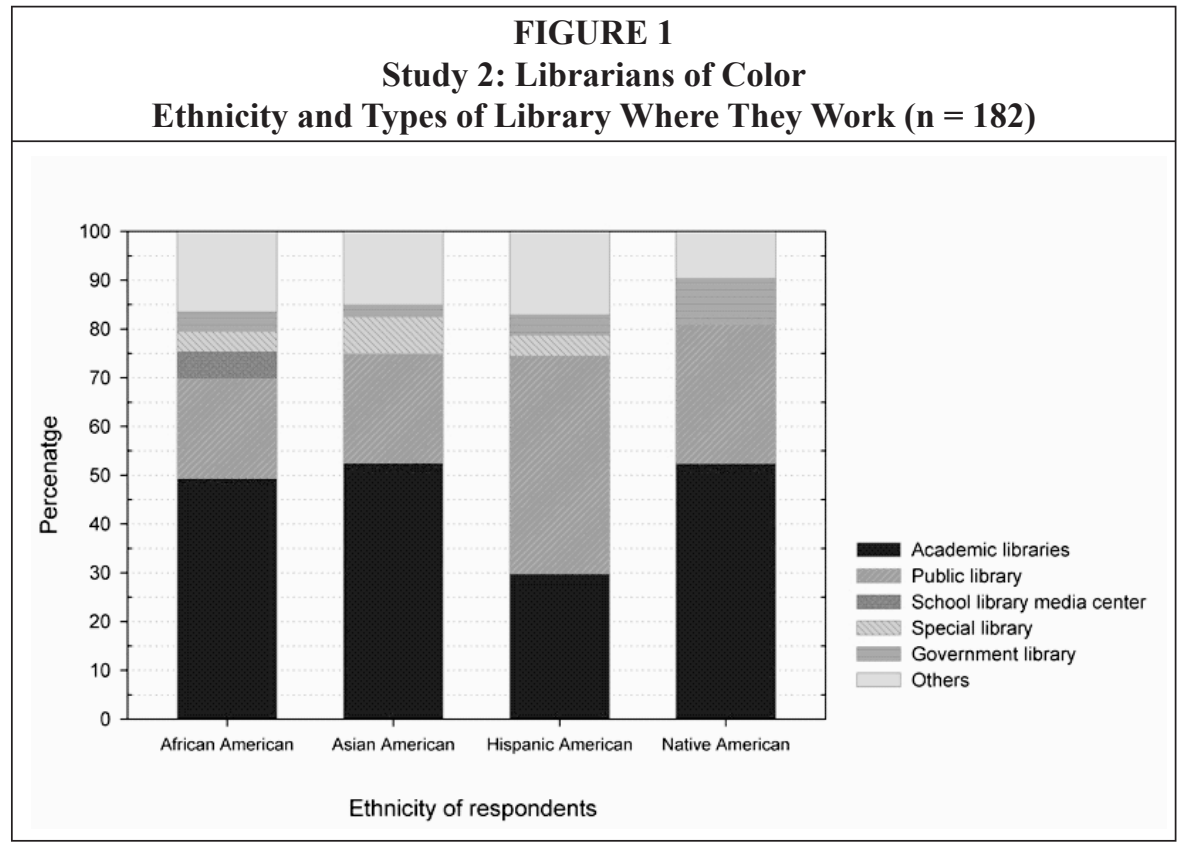

\begin{tabular}{|l|c|c|c|}
\hline \multicolumn{4}{|c|}{ TABLE 3 } \\
Study 1: Subject Specialists \\
Advanced Degree Holders by Subject Field and Degree Level (n = 206) \\
\hline \hline \multicolumn{1}{|c|}{ Subject Field } & Master's Degree & Doctoral Degree & Total \\
\hline Agriculture & $1(0.5 \%)$ & $0(0 \%)$ & $1(0.5 \%)$ \\
\hline Area Studies & $28(13.6 \%)$ & $4(1.9 \%)$ & $32(15.5 \%)$ \\
\hline Architecture & $1(0.5 \%)$ & $0(0 \%)$ & $1(0.5 \%)$ \\
\hline Art & $9(4.4 \%)$ & $1(0.5 \%)$ & $10(4.9 \%)$ \\
\hline Biological Sciences & $4(1.9 \%)$ & $5(2.4 \%)$ & $9(4.4 \%)$ \\
\hline Business & $9(4.4 \%)$ & $0(0 \%)$ & $9(4.4 \%)$ \\
\hline Education & $9(4.4 \%)$ & $1(0.5 \%)$ & $10(4.9 \%)$ \\
\hline $\begin{array}{l}\text { Engineering \& } \\
\text { Computer Science }\end{array}$ & $4(1.9 \%)$ & $0(0 \%)$ & $4(1.9 \%)$ \\
\hline Humanities & $49(23.8 \%)$ & $11(5.2 \%)$ & $60(29.1 \%)$ \\
\hline Law & $2(1.0 \%)$ & $10(4.9 \%)$ & $12(5.8 \%)$ \\
\hline Mathematics & $0(0 \%)$ & $0(0 \%)$ & $0(0 \%)$ \\
\hline Medicine & $2(1.0 \%)$ & $1(0.5 \%)$ & $3(1.4 \%)$ \\
\hline Music & $6(2.9 \%)$ & $4(1.9 \%)$ & $10(4.9 \%)$ \\
\hline Physical Sciences & $2(1.0 \%)$ & $2(1.0 \%)$ & $4(1.9 \%)$ \\
\hline Social Sciences & $34(16.5 \%)$ & $2(1.0 \%)$ & $36(17.5 \%)$ \\
\hline No answer & $4(1.9 \%)$ & $1(0.5 \%)$ & $5(2.4 \%)$ \\
\hline Total & $164(79.7 \%)$ & $42(20.3 \%)$ & $206(100.0 \%)$ \\
\hline
\end{tabular}


1 summarizes the result of the preferred library types. More than half of the participants $(53.7 \%)$ wanted to work in academic and research libraries. When the archives, considered as a type of research library, is added, 63.2 percent of the participants preferred academic/research libraries to other types.

When a Chi-square test was carried out to test the relationship between participants' education level and their preferred type of libraries, the result was statistically significant $\left(\chi^{2}=6.423, p<.05\right)$. It suggests that doctoral degree holders are more likely to prefer academic library/archive to other types of libraries (table 2).

Among the 182 participants of Study 2, seventy-nine of them (43.4\%) were working in academic libraries or archives. Academic librarians constitute the largest share of respondents for three out of four ethnic groups: 49.3 percent of African American, 52.5 percent of Asian American, and 52.4 percent of Native American respondents were working in academic and research libraries. Among Hispanic respondents, on the other hand, only 29.8 percent of them were in academic libraries, while 44.7 percent of them were in public libraries (figure 1). However, the Chi-square test revealed no statistically significant difference among different ethnic groups and library types $\left(\chi^{2}=7.316, p=.29\right)$.

As those who are currently employed in a given profession are similar to those who are likely candidates for recruitment into that profession, ${ }^{36}$ Studies 1 and 2 will focus on the responses from the participants who are interested in academic libraries and those currently working in such libraries, respectively (Study 1 on advanced degree holders: $n=206$; and Study 2 on librarians of color: $n=79$ ).

\section{Background of Respondents}

In Study 1, among those interested in academic and research libraries includ-
TABLE 4

Study 2: Librarians of Color

Librarians of Color by Ethnicity $(n=79)$

\begin{tabular}{|l|r|r|}
\hline Ethnicity & Frequency & $\begin{array}{r}\text { Percentage of } \\
\text { Cases* (n=79) }\end{array}$ \\
\hline African American & 36 & $45.6 \%$ \\
\hline $\begin{array}{l}\text { Asian American/ } \\
\text { Pacific Islander }\end{array}$ & 21 & $26.6 \%$ \\
\hline $\begin{array}{l}\text { Hispanic/Latino } \\
\text { Native American/ } \\
\text { Alaskan Native }\end{array}$ & 14 & $17.7 \%$ \\
\hline Total & 82 & $13.9 \%$ \\
\hline
\end{tabular}

As multiple responses were allowed for this question, Percentage of Cases column adds up to more than $00 \%$. For this question, seventy-nine participants proided a total of 82 responses.

ing archives $(n=206), 29.1$ percent of them had advanced degrees in humanities, 17.5 percent in social sciences, and 15.5 percent in area studies. Table 3 summarizes the number and percentage of advanced degree holders by fields and by degrees.

In Study 2, a majority of the academic librarian participants were African American (45.6\%). Asian Americans, Hispanics, and Native Americans constituted 26.6 percent, 17.7 percent, and 13.9 percent of the participants respectively (see table $4)$. More than one-third of them were bilingual or multilingual (36.7\%).

As far as their academic background is concerned, most of the academic librarian respondents in Study 2 had an undergraduate degree in social sciences $(32.9 \%)$ or humanities $(30.4 \%)$. About 34 percent of them had an additional master's degree in a field other than LIS. In addition, 10 percent of them held a doctoral degree: half of them in LIS, and the other half in other disciplines (table 5). A larger proportion of the academic librarian respondents held advanced degrees (including master's and doctoral degrees) in non-LIS fields, compared to nonacademic librarian respondents. Among nonacademic librarian respondents, 18 percent hold a master's degree and 4 percent hold a 


\begin{tabular}{|c|c|c|c|c|c|c|}
\hline Academic & Stu & $\begin{array}{l}\text { TAI } \\
\text { y 2: Libı } \\
\text { by Subje }\end{array}$ & $\begin{array}{l}\text { LE } 5 \\
\text { arians of C } \\
\text { t Field an }\end{array}$ & $\begin{array}{l}\text { Dlor } \\
\text { Degree }\end{array}$ & Cevel $(n=$ & \\
\hline Subject Fields & $\begin{array}{r}\text { UndergI } \\
\text { Deg }\end{array}$ & $\begin{array}{l}\text { duate } \\
\text { ee }\end{array}$ & Master's & Degree & Doctora & Degree \\
\hline & Number & $\begin{array}{c}\% \text { of } \\
\text { cases* } \\
(n=79)\end{array}$ & Number & $\begin{array}{c}\% \text { of } \\
\text { cases* } \\
(n=79)\end{array}$ & Number & $\begin{array}{c}\% \text { of } \\
\text { cases* } \\
(n=79)\end{array}$ \\
\hline Arts & 4 & $5.1 \%$ & 2 & $2.5 \%$ & 0 & $0.0 \%$ \\
\hline Business & 7 & $8.9 \%$ & 3 & $3.8 \%$ & 0 & $0.0 \%$ \\
\hline Education & 8 & $10.1 \%$ & 3 & $3.8 \%$ & 0 & $0.0 \%$ \\
\hline Humanities & 24 & $30.4 \%$ & 4 & $5.1 \%$ & 1 & $1.3 \%$ \\
\hline Laws & 0 & $0 \%$ & 3 & $3.8 \%$ & 1 & $1.3 \%$ \\
\hline LIS & 7 & $8.9 \%$ & 76 & $96.2 \%$ & 4 & $5.0 \%$ \\
\hline Medical Sciences & 3 & $3.8 \%$ & 1 & $1.3 \%$ & 0 & $0.0 \%$ \\
\hline Natural Sciences & 4 & $5.1 \%$ & 3 & $3.8 \%$ & 0 & $0.0 \%$ \\
\hline Social Sciences & 26 & $32.9 \%$ & 7 & $8.9 \%$ & 1 & $1.3 \%$ \\
\hline Other & 8 & $10.1 \%$ & 1 & $1.3 \%$ & 1 & $1.3 \%$ \\
\hline N/A & 0 & $0.0 \%$ & 1 & $1.3 \%$ & 71 & $89.8 \%$ \\
\hline Total & 91 & $115.2 \%$ & 103 & $130.4 \%$ & 79 & $100.0 \%$ \\
\hline
\end{tabular}

\begin{tabular}{|c|c|c|}
\hline \multicolumn{3}{|c|}{$\begin{array}{c}\text { TABLE } 6 \\
\text { Study 1: Subject Specialists } \\
\text { Types of Library Work Preferred by Advanced Degree Holders }(n=206)\end{array}$} \\
\hline $\begin{array}{l}\text { Type of Library Work } \\
\end{array}$ & Number & Percentage (\%) \\
\hline Reference and instruction & 95 & $46.1 \%$ \\
\hline Digital librarianship and digital collections & 23 & $11.2 \%$ \\
\hline Bibliography and collection management & 20 & $9.7 \%$ \\
\hline Cataloging and classification & 16 & $7.8 \%$ \\
\hline Faculty liaison & 15 & $7.3 \%$ \\
\hline Administration & 10 & $4.9 \%$ \\
\hline Not sure & 4 & $1.9 \%$ \\
\hline Preservation/Conservation & 3 & $1.4 \%$ \\
\hline Special collections & 3 & $1.4 \%$ \\
\hline Research & 2 & $1.0 \%$ \\
\hline Database design and computer technology & 2 & $1.0 \%$ \\
\hline Others & 10 & $4.9 \%$ \\
\hline No answer & 3 & $1.4 \%$ \\
\hline Total & 206 & $100 \%$ \\
\hline
\end{tabular}


doctoral degree in fields other than LIS.

Both studies suggest that there are more students from humanities and social sciences pursuing studies in LIS than those with a hard science background. This pattern is similar to the profile of LIS students in general. ${ }^{37}$ While the LIS field has been considered multidisciplinary, it tends to attract individuals from soft sciences more than those from hard sciences. As such an imbalance may result in a severe shortage of subject specialists in hard sciences, more recruiting efforts will need to be made to attract qualified individuals with a hard science background.

\section{Types of Library Work Preferred}

To investigate their specific career paths, respondents interested in academic and research libraries in Study 1 were asked to identify a specific type of library work they liked. The most preferred type was reference and instruction services (46.1\%), followed by digital library work (11.2\%), and bibliography/collection management $(9.7 \%)$. Table 6 summarizes the full results.

For the academic librarian participants in Study 2, upon receipt of their MLIS degree, a majority of them (68.3\%) found their first LIS-related job in public services (for instance, reference). While 16.5 percent of them had their first job in technical services (for instance, cataloging, acquisition), 3.8 percent started with administrative/managerial positions (table 7).

\section{Choosing Librarianship: Decision Time}

Information on the time when the participants developed their interest in LIS is valuable because it suggests the appropriate timing for recruitment. It is interesting to note that half of the participants in Study 1 responded that they became interested in LIS during or after their graduate studies (table 8). This finding coincides with the results of Mayer and Terrill's sur-
TABLE 7

Study 2: Librarians of Color

Types of Work - First Library Job $(n=79)$

\begin{tabular}{|l|r|r|}
\hline \multicolumn{1}{|c|}{ Type } & Number & $\begin{array}{r}\text { Percentage } \\
\text { of Cases * }\end{array}$ \\
\hline Public services & 54 & $68.3 \%$ \\
\hline Technical services & 13 & $16.5 \%$ \\
\hline $\begin{array}{l}\text { Administrative/ } \\
\text { Managerial position }\end{array}$ & 3 & $3.8 \%$ \\
\hline Director & 1 & $1.3 \%$ \\
\hline No answer & 11 & $13.9 \%$ \\
\hline Total & 82 & $103.8 \%$ \\
\hline
\end{tabular}

*As multiple responses were allowed for this question, the Percentage of Cases column adds up to more than $100 \%$. Seventy-nine participants provided a total of 82 responses. vey of academic librarians. In their study, about 41 percent of respondents with advanced-subject degrees indicated that they decided to become a librarian after receiving their subject degrees. ${ }^{38}$

The response from the academic librarians of color surveyed in Study 2 is rather mixed. Almost one third of the respondents $(29.1 \%)$ indicated that they decided to pursue LIS while they were working in a non-LIS field, 24 percent of them in their undergraduate programs, and 22.8 percent while working in the LIS field (figure 2). When the decision times were compared across ethnic groups, the same time periods made the top three except in one group: In the Asian American group, the top two decision times were the same (while working in a non-LIS field, and while in the undergraduate program), but the third one was while in their graduate programs.

Findings of the two studies suggest the key target groups for recruitment. For recruiting subject specialists, the main target group should include graduate students because many of them decide which profession to enter with their subject expertise while in graduate programs. For recruiting librarians of color, undergraduates and paraprofessionals in libraries should be targeted. Library 


\begin{tabular}{|c|c|c|}
\hline $\begin{array}{r}\text { TABLE 8 } \\
\text { Study 1: Subject Spec } \\
\text { Time When Advanced Degree Holders Becan }\end{array}$ & $\begin{array}{l}\text { ts } \\
\text { iterested }\end{array}$ & LIS $(n=206)$ \\
\hline Time & Number & Percentage (\%) \\
\hline During other graduate study & 57 & $27.7 \%$ \\
\hline During post-other graduate degree & 46 & $22.3 \%$ \\
\hline During undergraduate study & 22 & $10.7 \%$ \\
\hline After undergraduate, but before graduate study & 17 & $8.2 \%$ \\
\hline When working in the subject field & 15 & $7.3 \%$ \\
\hline Before undergraduate study & 12 & $5.8 \%$ \\
\hline When working in a library & 10 & $4.8 \%$ \\
\hline After undergraduate study & 8 & $3.9 \%$ \\
\hline When looking for a career or wanting a career change & 4 & $1.9 \%$ \\
\hline When facing an early retirement or unemployment & 3 & $1.5 \%$ \\
\hline Getting to know some librarians & 3 & $1.5 \%$ \\
\hline Others & 3 & $1.5 \%$ \\
\hline No answer & 6 & $2.9 \%$ \\
\hline Total & 206 & $100 \%$ \\
\hline
\end{tabular}

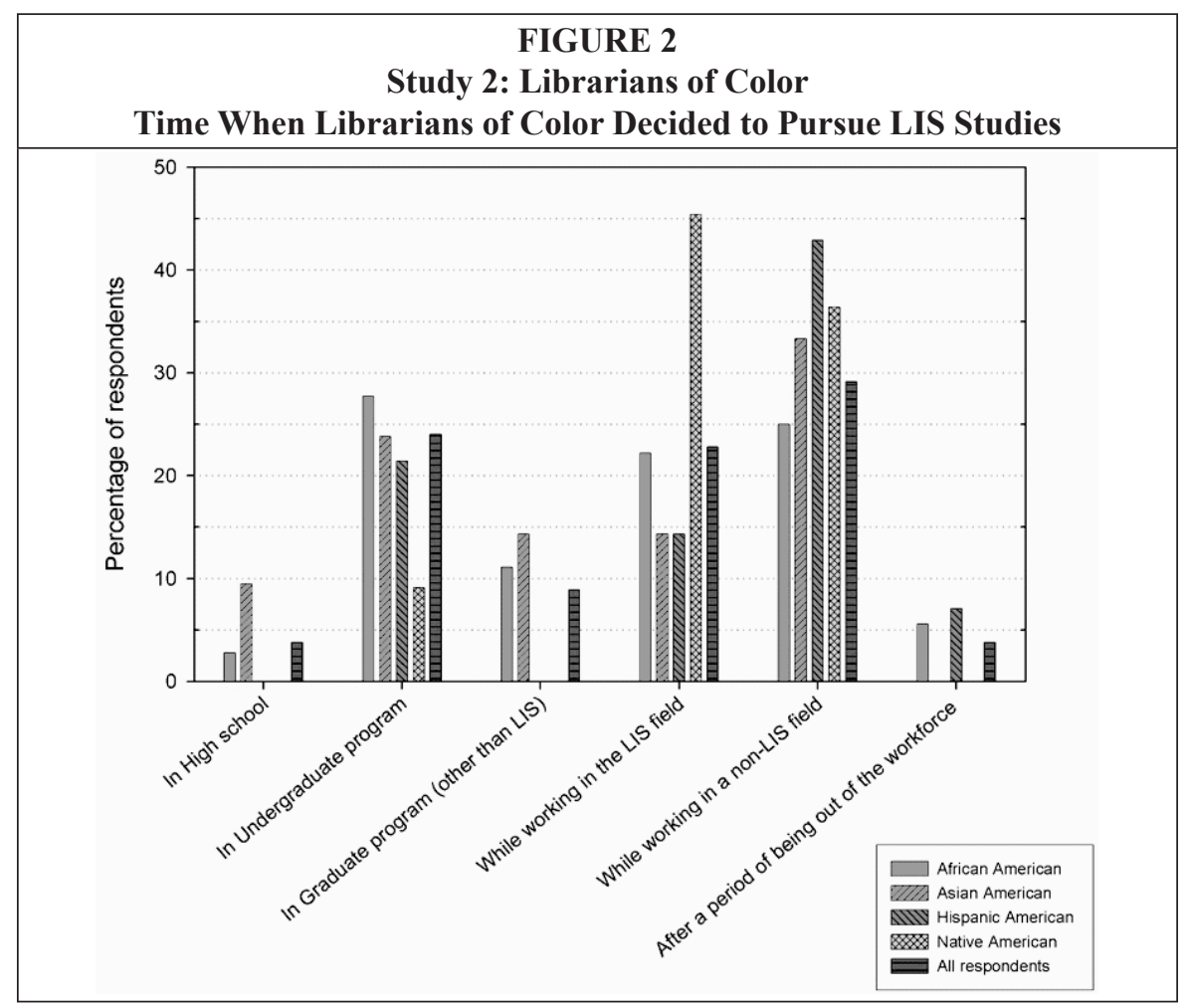




\begin{tabular}{|c|c|c|c|c|}
\hline \multicolumn{5}{|c|}{$\begin{array}{c}\text { TABLE } 9 \\
\text { Study 1: Subject Specialists } \\
\text { Primary and Secondary Factors Attracting Advanced Degree Holders to } \\
\text { Choose Librarianship }(n=206)\end{array}$} \\
\hline Factors & Primary & Secondary & $\begin{array}{c}\text { Total } \\
(\text { Prim+Sec })\end{array}$ & $\begin{array}{l}\text { Percentage } \\
\text { of Cases }\end{array}$ \\
\hline Intellectually rich environment & 46 & 51 & 97 & $23.5 \%$ \\
\hline Nature of the library work & 30 & 42 & 72 & $17.5 \%$ \\
\hline $\begin{array}{l}\text { Wanted academic job, but not } \\
\text { classroom teaching }\end{array}$ & 31 & 26 & 57 & $13.8 \%$ \\
\hline Experience of working in a library & 30 & 13 & 43 & $10.4 \%$ \\
\hline Quality of work life & 13 & 21 & 34 & $8.3 \%$ \\
\hline Scarcity of academic jobs & 17 & 11 & 28 & $6.8 \%$ \\
\hline $\begin{array}{l}\text { Cooperative rather than solitary and } \\
\text { competitive environment }\end{array}$ & 13 & 13 & 26 & $6.3 \%$ \\
\hline Role model of a particular librarian & 1 & 8 & 9 & $2.2 \%$ \\
\hline $\begin{array}{l}\text { Unpleasant experience with tenure } \\
\text { track position }\end{array}$ & 1 & 3 & 4 & $1.0 \%$ \\
\hline $\begin{array}{l}\text { Positive experience with doctoral } \\
\text { research }\end{array}$ & 0 & 2 & 2 & $0.5 \%$ \\
\hline Other & 20 & 10 & 30 & $7.3 \%$ \\
\hline No answer & 4 & 6 & 10 & $2.4 \%$ \\
\hline Total & 206 & 206 & 412 & $100 \%$ \\
\hline
\end{tabular}

associations and scholars have often regarded encouraging individuals working in libraries to seek an MLIS degree as a viable recruitment strategy. ${ }^{39}$ The findings of this study support this view.

In addition to recruiting those who are already working in libraries, more proactive recruitment is needed. In Study 2 , for example, many seem to believe that recruitment should target a wider range of groups, including high school students. In their response to open-ended questions in Study 2, a number of participants emphasized the need for bringing more promotion/recruitment campaigns to high schools. Although it did not make it into the top ten strategies (presented in table 11), about 30 percent of the respondents also selected "Presentation of the LIS program/career opportunities in high schools" as one of the important strategies. It is interesting to note that only
4 percent responded that they decided to pursue LIS studies while in high schools (see figure 2), which is similar to the result of Ard and her colleagues' study. Their study of MLIS students found that only 2 percent of the respondents decided to pursue LIS while in high schools. ${ }^{40}$ This might be an indication that, in the past, there had not been much aggressive promotion of the LIS professions/programs, targeting the high school students in particular, although it could have been effective. A review of recruitment literature of education, nursing, and engineering suggest that these professions are actively engaged in providing recruitment programs to high school students. ${ }^{41}$ To recruit more talent into the LIS professions, there should be more recruitment initiatives targeting high school students, such as school library clubs, teen library associations, school visits, and precollege 
library programs ${ }^{42}$ Such efforts can help reach students in their early stages of career choice and establish LIS as a viable career choice for them.

\section{Choosing Librarianship: Influential Fac- tors and Recruitment Strategies}

In Study 1, participants were asked to list the primary and secondary factors that attracted them to librarianship. The results suggest that the intellectually rich environment and the academic nature that a library position offers were the main factors that attracted them to the field (table 9). Experience of working in a library as well as quality of work life and collaborative work environment were also important factors.

In Study 1, the participants were also asked to list positive and negative aspects of choosing librarianship as a career, and the results are presented in table 10. The top three positive factors included: (1) ability to work in the field they love, (2) more job options, and (3) opportunities for career advancement. When asked to add other positive factors, the participants frequently mentioned career flexibility, highly energetic professionals, ability to use all the diverse academic education within the LIS field, and the fact that academic librarianship involves teaching, research, and service. Clearly, these aspects will need to be emphasized when marketing academic librarianship as a profession to advanced degree holders. Results also revealed the top three negative factors: (1) low salary, (2) high cost for education, and (3) low funding for education. Other negative factor included lack of job security. These negative factors highlight the challenges that the library profession must overcome to recruit qualified individuals to LIS.

Findings of Study 2 identified effective recruitment strategies, some of which are comparable to what was found in Study 1. In Study 2, respondents were asked to select the top ten recruitment strategies out of twenty-seven strategies, and the results are shown in table 11 . The top ten strategies can be organized into four groups:

\begin{tabular}{|c|c|c|c|}
\hline \multicolumn{4}{|c|}{$\begin{array}{c}\text { TABLE } 10 \\
\text { Study 1: Subject Specialists } \\
\text { Positive and Negative Aspects of Choosing Librarianship } \\
\text { as a Career }(\mathrm{n}=\mathbf{2 0 6})\end{array}$} \\
\hline Aspects & Positive & Negative & $\begin{array}{c}\text { No } \\
\text { Opinion }\end{array}$ \\
\hline Ability to work in the field I love & $90 \%$ & $0 \%$ & $10 \%$ \\
\hline Career advancement & $68 \%$ & $8 \%$ & $24 \%$ \\
\hline Cost & $29 \%$ & $35 \%$ & $36 \%$ \\
\hline Family obligations & $21 \%$ & $16 \%$ & $63 \%$ \\
\hline Funding & $15 \%$ & $34 \%$ & $50 \%$ \\
\hline Geographic mobility & $61 \%$ & $12 \%$ & $27 \%$ \\
\hline Job options & $83 \%$ & $8 \%$ & $9 \%$ \\
\hline Opinions of colleagues in my subject field & $32 \%$ & $13 \%$ & $55 \%$ \\
\hline Opinions of subject area professors & $24 \%$ & $13 \%$ & $63 \%$ \\
\hline Salary & $29 \%$ & $45 \%$ & $26 \%$ \\
\hline Status of librarian & $31 \%$ & $34 \%$ & $35 \%$ \\
\hline Time required to earn a degree & $43 \%$ & $29 \%$ & $29 \%$ \\
\hline Other, specify & $27 \%$ & $3 \%$ & $70 \%$ \\
\hline
\end{tabular}


Recruiting a Diverse Workforce for Academic/Research Librarianship 545

\begin{tabular}{|c|c|c|}
\hline \multicolumn{3}{|c|}{$\begin{array}{c}\text { TABLE } 11 \\
\text { Study 2: Librarians of Color } \\
\text { Top Ten Recruitment Strategies }\end{array}$} \\
\hline Rank & Recruitment Strategy & $\begin{array}{l}\% \text { of Cases } \\
(n=79)\end{array}$ \\
\hline 1 & Assistantship/scholarship/financial aid & $82.30 \%$ \\
\hline 2 & Role models of your or other ethnic group & $69.60 \%$ \\
\hline 3 & Ethnic diversity of faculty in the LIS school/program & $64.60 \%$ \\
\hline 4 & Presence of faculty and staff of color in the recruitment process & $63.30 \%$ \\
\hline 5 & Opportunities for students of color to work in the LIS field & $53.20 \%$ \\
\hline 6 & $\begin{array}{l}\text { Communication /Advertising in media, publications for people of } \\
\text { color }\end{array}$ & $49.40 \%$ \\
\hline 7 & $\begin{array}{l}\text { Special programs (Opportunities to work with LIS faculty, graduate } \\
\text { students, or librarians) }\end{array}$ & $48.10 \%$ \\
\hline 8 & Presence of alumni of color in the recruitment process & $45.60 \%$ \\
\hline 8 & Recruitment materials developed especially for students of color & $45.60 \%$ \\
\hline 10 & Active solicitation and personal contacts from the LIS school/program & $44.30 \%$ \\
\hline
\end{tabular}

(1) financial and work opportunities (for example, scholarship/financial aids, work opportunities including special programs in LIS); (2) recruitment process (for instance, active solicitation and personal contacts, tailored recruitment materials, presence of faculty, staff, and alumni of color in the recruitment process); (3) ethnic diversity (for instance, diversity of LIS faculty, role models), and (4) advertising (for example, communication through media for minority groups).

Both Studies 1 and 2 pointed to the importance of financial support in LIS education. In Study 2, "Assistantship/ scholarship/financial aid" was found to be the most effective recruitment strategy (ranked top, selected by 82.3 percent of the respondents). This coincides with findings of Study 1, which identified the high cost for education and low funding for education as detrimental to the pursuit of LIS education and career. The results from both studies support the views of most LIS recruitment literature, where the importance of financial support is often discussed and emphasized. ${ }^{43}$

In addition, previous library work experience has been highlighted as an important factor in both studies. In Study 2 , about 43 percent of the respondents identified previous library work experience as one of the factors affecting their decisions to pursue LIS (figure 3). This is related to Study 1, where "Experience of working in a library" was selected among the top five positive factors related to the choice of librarianship as career (see table 9). The results concur with Gordon and Nesbeitt's survey of librarians and Ard and her colleagues' survey of LIS students. In their studies, previous library experience was found to be one of the top factors affecting the decision to pursue a career in LIS. ${ }^{44}$ These findings again confirm that students and paraprofessionals working in libraries should be one of the key target groups for our recruitment efforts. In addition, they suggest that more working or volunteering opportunities in libraries should be used as a recruitment strategy.

Findings of Study 2 seem to offer further insights. When librarians of color were asked to list their top strategies for recruitment in Study 2, "Opportunities for students of color to work in the LIS field" was ranked 5 th (selected by 53.2 percent 


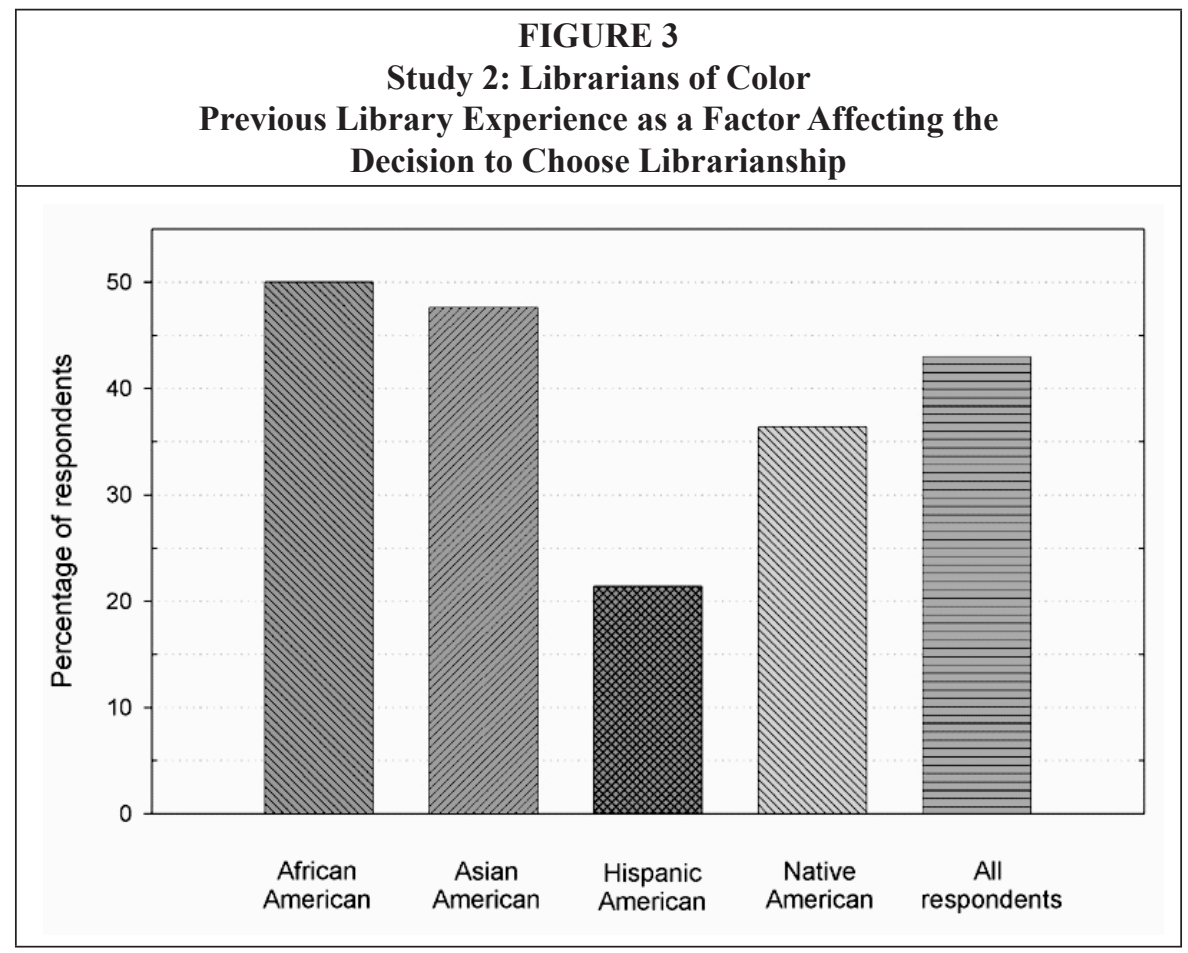

of respondents), and "Special programs (Opportunities to work with LIS faculty, graduate students, or librarians)" was the 7th (selected by 48.1 percent of respondents) (see table 11). These kinds of programs can achieve several objectives at the same time. Through such programs, students can learn what the LIS field is about. They can also meet with some authoritative figures who can be their role models as well as mentors. Variations of such programs have been offered in other fields to recruit students (for instance, precollege bridge programs in engineering, nursing) ${ }^{45}$ It would be worthwhile to develop and offer such special programs to recruit more students into LIS.

While sharing similar findings as discussed above, Studies 1 and 2 also revealed some differences in terms of the perceived effectiveness of some recruitment strategies. One of the notable differences is the influence of role models on career choice. In Study 1, role models did not seem to have a strong impact among the advanced degree holders: only 2.2 percent of the respondents selected role models as an influential factor (see table 9). This is different from other previous studies that pointed out the importance of role models in helping individuals to pursue LIS. ${ }^{46}$ In Study 2, on the other hand, the finding concerning role models is more consistent with extant studies. Strategy "Role models of your or other ethnic group" was selected by 69.6 percent of the respondents, making the strategy the second-most selected strategy, following the strategy of assistantship/financial aid (see table 11).

As role models seem to be important in recruitment in general, a question worth further exploring is: "Who are the role models that can motivate individuals to pursue studies in LIS?" Findings of Study 2 offer some insights on this issue (Figure 4). The most influential figures include academic librarians (selected by 39.2 percent of the respondents) and public librarians (selected by 21.5 percent). 
The influence of academic librarians is especially prominent among the African American and the Hispanic respondents. In Asian American and Native American groups, on the other hand, friends and family are found to have significant influence. Teachers and faculty members seem to have significant influence among Native Americans.

An interesting finding from Study 2 is that the recruiters and their personal touch can have a surprisingly big impact on recruitment as almost half of the top ten strategies are related to this. Role models, as discussed above, was ranked second in the top ten recruitment strategies (see table 11). Presence of faculty/staff of color and presence of alumni of color in the recruitment process were ranked as 4th and 8th, respectively. Active solicitation and personal contacts from the LIS school/program also made the top ten. The positive influence of having ethnically diverse faculty in LIS programs is often mentioned in LIS recruitment studies, ${ }^{47}$ and the findings of this study support this view, with the strategy ranked 3rd. Although it is clear that using diverse recruiters and a personal touch would be helpful in recruitment, the benefit of such strategies is less discussed in LIS literature. Given that these recruitment strategies are relatively less demanding in terms of the financial requirement for the LIS schools, and that they have been adopted in recruitment campaigns of other professions, ${ }^{48}$ such efforts should be an area that needs more attention in LIS.

Differences found between advanced degree holders and the librarians of color in their preferred strategies highlight the need for more specialized and tailored recruitment campaigns. To explore more of possible group differences in recruitment strategies, responses from Study 2 were further analyzed. The top ten strategies of different ethnic groups were tabulated, and some differences were

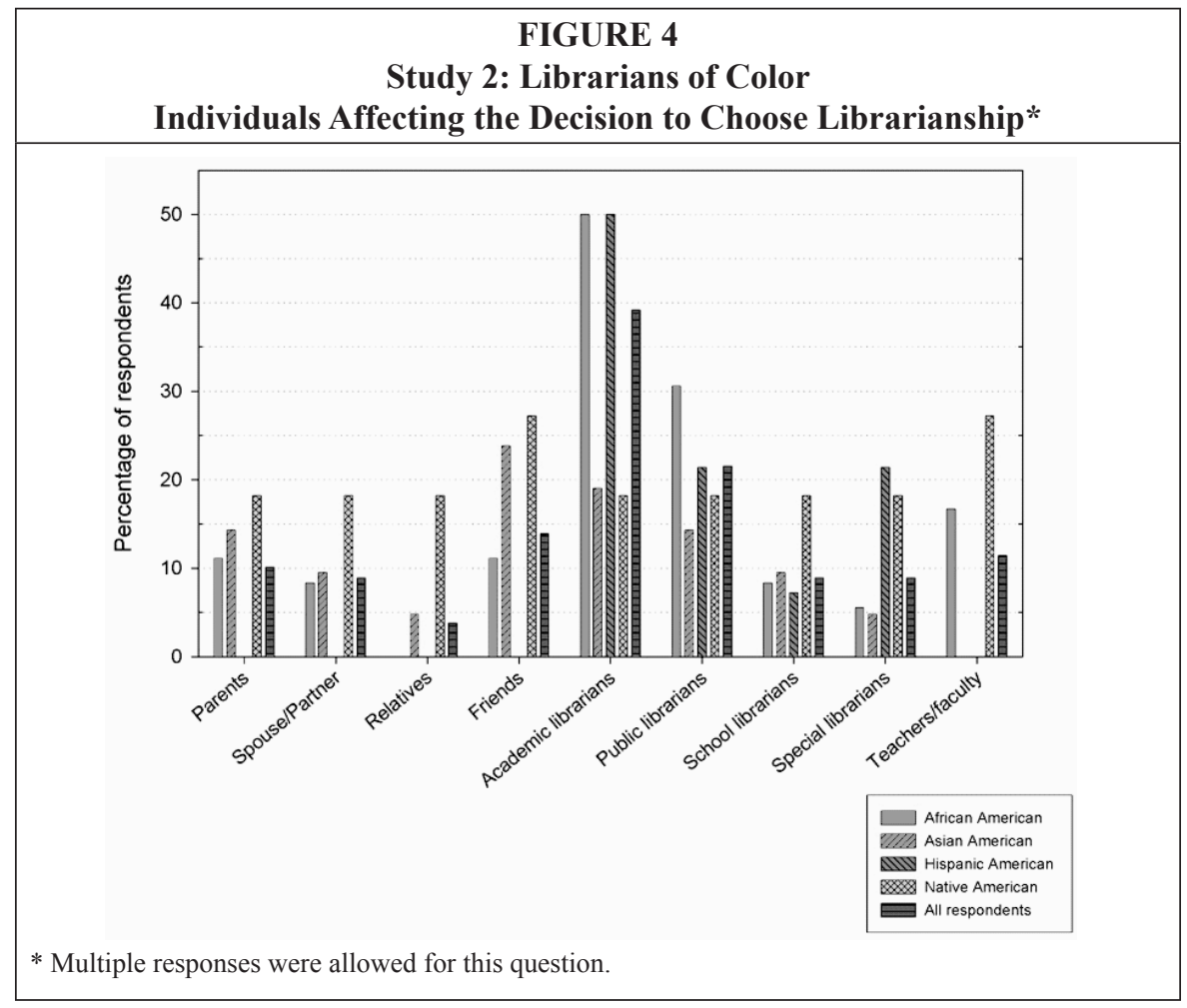




\begin{tabular}{|c|c|c|c|c|c|c|}
\hline \multicolumn{7}{|c|}{$\begin{array}{c}\text { TABLE 12 } \\
\text { Study 2: Librarians of Color } \\
\text { Top Ten Recruitment Strategies by Ethnic Groups }\end{array}$} \\
\hline Strategy & $\begin{array}{l}\text { Afr. } \\
\text { Am. }\end{array}$ & $\begin{array}{l}\text { Asian } \\
\text { Am. }\end{array}$ & $\begin{array}{l}\text { His. } \\
\text { Am. }\end{array}$ & $\begin{array}{l}\text { Native } \\
\text { Am. }\end{array}$ & $\begin{array}{c}\text { Overall } \\
\text { Rank }\end{array}$ & $\begin{array}{l}\chi^{2} \text { test } \\
\text { p-value }\end{array}$ \\
\hline \multicolumn{7}{|l|}{ Advertising } \\
\hline $\begin{array}{l}\text { Communication/Advertising in media, } \\
\text { publications for people of color }\end{array}$ & $2 \mathrm{nd}$ & - & - & - & 6 th & 0.067 \\
\hline $\begin{array}{l}\text { Presentation of the LIS program/ca- } \\
\text { reer opportunities in high schools }\end{array}$ & 7 th & - & - & - & - & $0.001 * *$ \\
\hline $\begin{array}{l}\text { Presentation of the LIS program/career } \\
\text { opportunities in undergraduate classes }\end{array}$ & - & - & 9 th & - & - & $0.043^{*}$ \\
\hline \multicolumn{7}{|l|}{ Recruitment Process } \\
\hline $\begin{array}{l}\text { Presence of faculty and staff of color } \\
\text { in the recruitment process }\end{array}$ & $3 \mathrm{rd}$ & 4 th & 4 th & 5 th & 4 th & 0.953 \\
\hline $\begin{array}{l}\text { Presence of alumni of color in the } \\
\text { recruitment process }\end{array}$ & - & 7 th & 9 th & 2 nd & 8 th & $0.039^{*}$ \\
\hline $\begin{array}{l}\text { Active solicitation and personal con- } \\
\text { tacts from the LIS school/program }\end{array}$ & - & 10 th & 6 th & 9 th & 10 th & 0.907 \\
\hline $\begin{array}{l}\text { Recruitment materials developed } \\
\text { especially for students of color }\end{array}$ & 6 th & - & - & 8 th & 8 th & 0.444 \\
\hline \multicolumn{7}{|l|}{ Ethnic diversity } \\
\hline $\begin{array}{l}\text { Role models of your or other ethnic } \\
\text { group }\end{array}$ & $3 \mathrm{rd}$ & 2 nd & $1 \mathrm{st}$ & 4 th & 2 nd & 0.670 \\
\hline $\begin{array}{l}\text { Ethnic diversity of faculty in the LIS } \\
\text { school/program }\end{array}$ & 5 th & $2 \mathrm{nd}$ & 4 th & $2 \mathrm{nd}$ & $3 \mathrm{rd}$ & 0.305 \\
\hline $\begin{array}{l}\text { Ethnic diversity of student population } \\
\text { in the LIS school/program }\end{array}$ & & 6 th & - & 9 th & - & 0.189 \\
\hline $\begin{array}{l}\text { Existence of committees/systems rein- } \\
\text { forcing diversity/antidiscrimination in } \\
\text { the LIS school/program }\end{array}$ & - & - & 6 th & - & - & $0.016^{*}$ \\
\hline \multicolumn{7}{|l|}{ Financial and work opportunities } \\
\hline Assistantship/scholarship/financial aid & $1 \mathrm{st}$ & $1 \mathrm{st}$ & $1 \mathrm{st}$ & $1 \mathrm{st}$ & 1 st & 0.860 \\
\hline $\begin{array}{l}\text { Opportunities for students of color to } \\
\text { work in the LIS field }\end{array}$ & 8 th & 4 th & 6 th & 5 th & 5 th & 0.474 \\
\hline $\begin{array}{l}\text { Special programs (Opportunities to } \\
\text { work with LIS faculty, graduate stu- } \\
\text { dents, or librarians) }\end{array}$ & 8 th & 10 th & $3 \mathrm{rd}$ & 9 th & 7 th & 0.631 \\
\hline $\begin{array}{l}\text { Availability of career services/job } \\
\text { placement in the LIS school/program }\end{array}$ & 8 th & 7 th & - & - & - & 0.064 \\
\hline \multicolumn{7}{|l|}{ Program/Curriculum } \\
\hline $\begin{array}{l}\text { Courses on diversity/multicultural } \\
\text { issues }\end{array}$ & - & 9 th & 9 th & 9 th & - & 0.284 \\
\hline $\begin{array}{l}\text { Distance learning options in the LIS } \\
\text { school/program }\end{array}$ & - & - & - & 5 th & - & $0.012 *$ \\
\hline
\end{tabular}


found in their preferred strategies (table 12). Chi-square tests revealed that there was a significant difference among groups in five strategies. Relatively more Native American respondents value two strategies highly: "Distance learning options in the LIS school/program" and "Presence of alumni of color in the recruitment process." Among the Hispanic American and Asian American respondents, "Existence of committees/systems reinforcing diversity/antidiscrimination in the LIS school/program" received a higher share of support. A higher proportion of the African American respondents selected "Presentation of the LIS program/career opportunities" in high schools as well as undergraduate classes. Although these ethnic groups were often grouped together as the "minority," the findings support the view that there are distinguishing differences among different groups, and these differences should be reflected in the recruitment strategies and recruitment materials. ${ }^{49}$

\section{Conclusion}

The literature on academic librarianship has underscored the importance of subject specialists and the benefits they bring to the academic and research library community. The value of cultural and ethnic diversity in librarianship has also been emphasized, as diversity helps the provision of better information services to the increasingly diverse user community, and the better performance of libraries and librarians. ${ }^{50}$ However, little has been known about the preferences of those with subject and cultural/language expertise, and factors/strategies important for their recruitment. While many LIS organizations have pledged their commitment to diversity, the dearth of such research could hinder future assessment and implementation of recruitment efforts.

By studying the views and experiences of the advanced degree holders and those of the librarians of color, this research provides more insight into the factors and recruitment strategies that could lead to a more diverse workforce in the LIS field. Findings of studies 1 and 2 show that providing financial support and opportunities to work in LIS would be beneficial to the recruitment of both advanced degree holders and people of color. The findings also revealed some differences, however. Role models, for example, seem to play a much stronger role among librarians of color than among advanced degree holders. The influence and contribution of academic librarians in motivating and mentoring future LIS professionals is also more evident among the librarians of color. This and other differences among groups underscore the need for more targeted recruitment campaigns.

Developing tailor-made strategies to reflect the culture, views, and concerns of a target group requires more understanding of the potential recruits' perspectives. While the findings of the two studies are not intended to be generalized to all LIS professionals, they can shed light on the experience and preference of individuals interested in becoming subject specialists and librarians of color. This paper is one of the beginning steps to give voice to the views of the recruits, which will strengthen the recruitment effort of LIS education and profession. There are still several areas that need future research: (1) large-scale studies employing a probability sampling method to increase the external validity of the research findings; (2) surveys focusing on the perspectives of particular librarian groups (for instance, public librarians, technical services librarians, male librarians, subject specialists in hard sciences); (3) studies using qualitative methods (for example, interviews, focus groups) to further the understanding of target groups; and (4) studies investigating strategies to make diversity part of organizational culture and to effectively retain recruited librarians. As clearly articulated by the ACRL and many other researchers and practitioners, the recruitment, education, and retention 
of librarians is an important issue facing academic libraries. Further research and proactive efforts in this area are of paramount importance for the continuing growth of academic librarianship in this new century.

\section{Notes}

1. William M. Curran, "Succession: The Next Ones at Bat," College \& Research Libraries 64, no. 2 (2003): 134-40.

2. Stanley Wilder, Demographic Change in Academic Librarianship (Washington, D.C.: Association of Research Libraries, 2003).

3. Mary Jo Lynch, "Vacancies: How Many? Where? Why?" Library Personnel News 15, no. 4 (2002): 1-3.

4. U.S. Census Bureau, "2001 Statistical Abstract of the United States," (2001). Available online at www.census.gov/prod/2002pubs/01statab/stat-ab01.html. [Accessed 1 October 2003].

5. John W. Berry, "Addressing the Recruitment and Diversity Crisis," American Libraries 33, no. 2 (2002): 7.

6. Joan S. Howland, "Beyond Recruitment: Retention and Promotion Strategies to Ensure Diversity and Success," Library Administration \& Management 13, no. 1 (1999): 4-14.

7. W. Lee Hisle, "Top Issues Facing Academic Libraries," College \& Research Libraries News 63, no. 10 (2002): 714-15, 730.

8. Mark D. Winston, "Recruitment Theory: Identification of Those Who Are Likely to Be Successful as Leaders," Journal of Library Administration 32, no. 3/4 (2001): 19-33.

9. Anne Beth Liebman Gibbs, "Subject Specialization in the Scientific Special Library," Special Libraries 84 (1993): 1-8.

10. Ellen Gay Detlefsen, "Specialists as Professionals in Research Libraries: An Overview of Trends and an Analysis of Job Announcements," Library Trends 41 (1992): 187-97; Ellen Gay Detlefsen and Josephine E. Olson, "The Special Librarian: Results from a Survey of MLS and MBA Graduates," Special Libraries 81 (1990): 294-304.

11. Gary W. White, "Academic Subject Specialist Positions in the United States: A Content Analysis of Announcements from 1990 through 1998," Journal of Academic Librarianship 25, no. 5 (1999): 372-82.

12. E. Smith, "The Impact of the Subject Specialist Librarian on the Organization and Structure of the Academic Research Library," The Academic Library: Essays in Honor of Guy R. Lyle, eds. Evan Ira Farber and Ruth Walling (Metuchen, N.J.: Scarecrow, 1974).

13. John Rodwell, "Dinosaur or Dynamo? The Future for the Subject Specialist Reference Librarian," New Library World 102, no. 1/2 (2001): 48-52.

14. Lynn Barstis Williams, "Subject Knowledge for Subject Specialists: What the Novice Bibliographer Needs to Know," Collection Management 14, no. 3-4 (1991): 31-47.

15. American Library Association. Office for Library Personnel Resources, Academic and Public Librarians: Data by Race, Ethnicity and Sex (Chicago: ALA, 1986).

16. Mary Jo Lynch, Stephen Tordella, and Thomas Godfrey, "Retirement and Recruitment: A Deeper Look," American Libraries 36 (2005): 28.

17. PUMS, Decision Demographics. Census Public Use Microdata File (2004).

18. Minority Business Development Agency, "Dynamic Diversity: Projected Changes in U.S. Race and Ethnic Composition 1995 to 2050" (1999). Available online at www.mbda.gov/documents/unpubtext.pdf. [Accessed 18 June 2005].

19. E. J. Josey, "Students in Library and Information Science," Library and Information Studies Education in the United States, eds. Loriene Roy and Brooke E. Sheldon (Washington: Mansell, 1998), 49-64.

20. Mary N. Hernandez, "Mentoring, Networking and Supervision: Parallelogram, Vortex, or Merging Point?" Reference Librarian, no. 45-46 (1994): 15-22; Michalle E. Mor Barak, David A. Cherin, and Sherry Berkman, "Organizational and Personal Dimensions in Diversity Climate," Journal of Applied Behavioral Science 34, no. 1 (1998): 82104.

21. U.S. Department of Education. National Center for Education Statistics, "The Condition of Education 2005," (U.S. Government Printing Office, 2005). Available online at http://nces. ed.gov/pubsearch/pubsinfo.asp?pubid=2005094. [Accessed 20 June 2005].

22. IIENetwork, "Open Doors 2004. International Student and Total U.S. Enrollment," (2004). Available online at http://opendoors.iienetwork.org/?p=49931. [Accessed 4 December 2004].

23. Karen Downing, "Diversity in the Undergraduate Library," Cultural Diversity in Libraries, eds. Donald E. Riggs and Patricia A. Tarin (New York: Neal-Schuman, 1994), 149-63. 


\section{Recruiting a Diverse Workforce for Academic/Research Librarianship 551}

24. Robert P. Haro, Developing Library and Information Services for Americans of Hispanic Origin (Metuchen, N.J.: Scarecrow Press, 1981).

25. Richard Parmater, "Point of Intersection: The University Library and the Pluralistic Campus Community," Information Reports and Bibliographies 19, no. 3 (1990): 2-10.

26. John N. Berry, “LIS Recruiting: Does It Make the Grade?" Library Journal 128, no. 8 (2003): 38-41; Lois L. Buttlar and William Caynon, "Recruitment of Librarians into the Profession: The Minority Perspective," Library \& Information Science Research 14 (1992): 259-80; Claudia J. Gollop, "Library and Information Science Education: Preparing Librarians for a Multicultural Society," College E Research Libraries 60, no. 4 (1999): 385-95; Lynch, Tordella, and Godfrey, "Retirement and Recruitment," 28.

27. Paula T. Kaufman, "Where Do the Next 'We' Come From? Recruiting, Retaining, and Developing Our Successors," ARL, no. 221 (2002): 1-5.

28. Emma Bradford Perry, "Let Recruitment Begin with Me," American Libraries 35, no. 5 (2004): 36-38.

29. Patricia S. Kuntz, "The Training of an Africana Librarian: The Mellon Fellowship," Journal of Education for Library and Information Science 44, no. 3/4 (2003): 316-31.

30. Association of Research Libraries, "Special Collections in ARL Libraries" (2003). Available online at www.arl.org/collect/spcoll/principles.html. [Accessed 20 June 2005].

31. Gollop, "Library and Information Science Education," 385-95

32. Raquel V. Cogell and Cindy A. Gruwell, Diversity in Libraries: Academic Residency Programs (Westport, Conn.: Greenwood Press, 2001).

33. Association of Research Libraries, "ARL Initiative to Recruit a Diverse Workforce," $A R L$, no. 210 (2000): 16.

34. Ann Knight Randall, "Minority Recruitment in Librarianship," Librarians for the New Millennium, eds. William E. Moen and Kathleen M. Heim (American Library Association, Office for Library Personnel Resources, 1988), 11-25; Buttlar and Caynon, "Recruitment of Librarians into the Profession," 259-80; Kathleen de la Pena McCook and Kate Lippincott, Planning for a Diverse Workforce in Library and Information Science Professions. Rev. Ed. (Tampa, Fla.: University of South Florida, School of Library and Information Science, Research Group, 1997); Gollop, "Library and Information Science Education," 385-95;

35. Association of College \& Research Libraries, Recruitment, Retention \& Restructuring: Human Resources in Academic Libraries (Chicago: Association of College and Research Libraries, 2002); Wilder, Demographic Change in Academic Librarianship.

36. Winston, "Recruitment Theory," 19-33.

37. Kathleen M. Heim and William E. Moen, Occupational Entry: Library and Information Science Students' Attitudes, Demographics and Aspirations Survey (Chicago: American Library Association, Office for Library Personnel Resources, 1989).

38. Jennifer Mayer and Lori J. Terrill, "Academic Librarians' Attitudes About Advanced-Subject Degrees," College E Research Libraries 66, no. 1 (2005): 59-73.

39. Randall, "Minority Recruitment in Librarianship," 11-25; Jen Stevens and Rosemary Streatfeild, Recruitment and Retention. Vol. 276, Spec Kit (Washington, D.C.: Office of Management Services, Association of Research Libraries, 2003).

40. Allyson Ard, Susan Clemmons, Nathan Morgan, Patrick Sessions, Brett Spencer, Tracy Tidwell, and Patricia J. West, "Why Library and Information Science?" Reference E User Services Quarterly 45, no. 3 (2006): 236-48.

41. Judith A. Torres, Kristin Latina, and Jessica Swedlow, "Minority Teacher Recruitment, Development, and Retention" (Education Alliance at Brown University; Northeast and Islands Regional Educational Laboratory, 2004), available online at www.alliance.brown.edu/pubs/ minority\%5Fteacher/minteachrcrt.pdf [Accessed 20 June 2004); H. Janiszewski Goodin, "The Nursing Shortage in the United States of America: An Integrative Review of the Literature," Journal of Advanced Nursing 43 (2003): 335-43; F. Summers Michael and A. Hrabowski Freeman, III, "Preparing Minority Scientists and Engineers," Science 311, no. 5769 (2006): 1870; Campbell George, Jr., "Support Them and They Will Come," Issues in Science and Technology 16, no. 2 (1999): 21.

42. Gregory. L. Reese and Ernestine L. Hawkins, Stop Talking, Start Doing! Attracting People of Color to the Library Profession (Chicago: ALA, 1999).

43. Buttlar and Caynon, "Recruitment of Librarians into the Profession," 259-80; Kathleen de la Pena McCook and Kate Lippincott, "Library Schools and Diversity: Who Makes the Grade?" Library Journal 122 (1997): 30-32; Heim and Moen, Occupational Entry.

44. Rachel Singer Gordon and Sarah Nesbeitt, "Who We Are, Where We're Going: A Report from the Front," Library Journal 124, no. 9 (May 15, 1999): 36-39; Ard and others, "Why Library and Information Science?" 236-48.

45. Tony D. Marable, "The Role of Student Mentors in a Precollege Engineering Program," 
Peabody Journal of Education 74, no. 2 (1999): 44-54; Sandra Millon Underwood and T. H. Fay, "The UWM Health Careers Bridge Program: An Innovative Approach for Improving the Recruitment, Retention and Graduation of Minority Students in Nursing and Health Careers," Journal of Nursing Education 35 (1996): 179-81.

46. Barbara I. Dewey, "Selection of Librarianship as a Career: Implications for Recruitment," Journal of Education for Library and Information Science 26 (1985): 16; Mara Houdyshell, Patricia A. Robles, and Hua Yi, "What Were You Thinking? If You Could Choose Librarianship Again, Would You?" Information Outlook3, no. 7 (1999): 19-23; Kathleen de la Pena McCook and William E. Moen, "Patterns of Program Selection: Ranked Factors in the Choice of a Master's Degree Program in Library and Information Studies," Journal of Education for Library and Information Science 33, no. 3 (1992): 212-25.

47. Randall, "Minority Recruitment in Librarianship," 11-25; McCook and Lippincott, Planning for a Diverse Workforce; Teresa Y. Neely, "Minority Student Recruitment in LIS Education: New Profiles for Success," Unfinished Business: Race, Equity, and Diversity in Library and Information Science Education, edited by M.B. Wheeler (Lanham, Md.: Scarecrow, 2005), 93-117.

48. Jerrold Hopfengardner and Thomas Lasley, "Teacher Recruitment: Recommendations for Program Implementation," Teacher Certification, ed. Gayle C Hall (Bloomington, Ind.: Phi Delta Kappa Center on Evaluation, Development and Research, 1985), 61-78; W. R. Hammond, and B. Yung, "Minority Student Recruitment and Retention Practices among Schools of Professional Psychology: A National Survey and Analysis," Professional Psychology-Research and Practice 24, no. 1 (1993): 3-12.

49. Reese and Hawkins, Stop Talking, Start Doing!

50. Mark D. Winston, "Communication and Difficult Topics in LIS Education: Teaching and Learning about Diversity in the Classroom," Unfinished Business: Race, Equity, and Diversity in Library and Information Science Education, ed. Maurice B. Wheeler (Lanham, Md.: Scarecrow Press, 2005), 171-80.

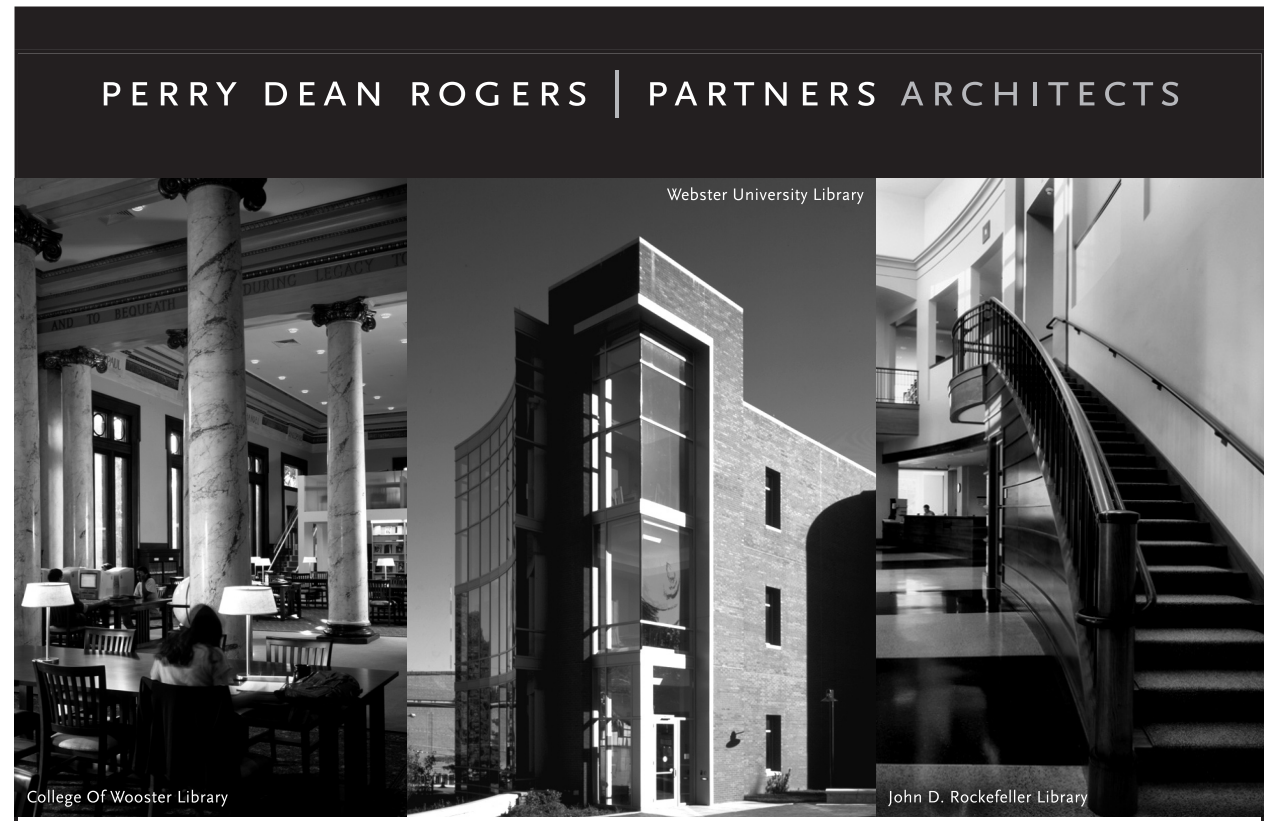

Designers for Libraries \& Academic Institutions

177 milk street boston massachusetts 02109 t 6174230100 f 6174262274 w perrydean.com 


\section{TAP into A New World OF Online Reviews}

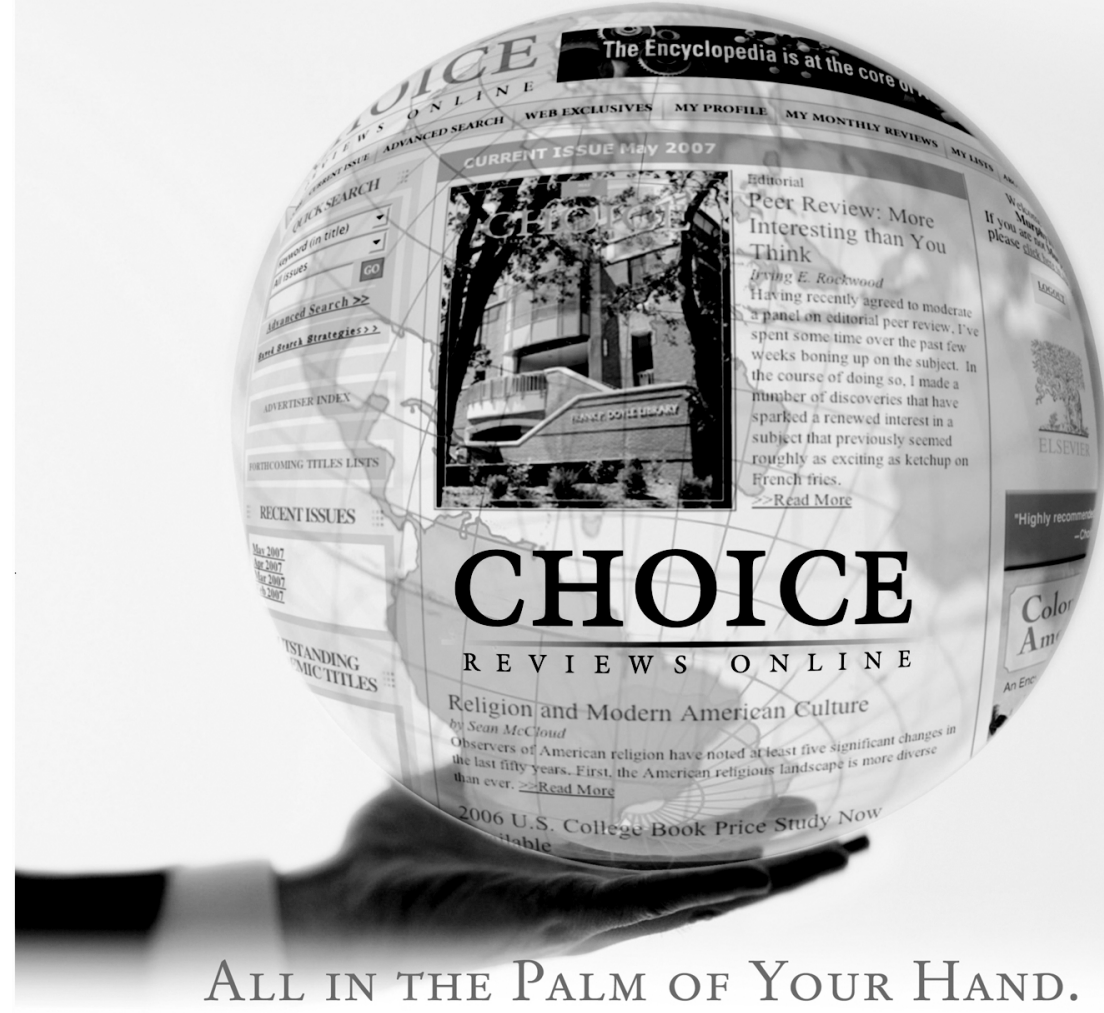

- Access to over 120,000 Choice Reviews

- Advanced Search Capabilities

- Enhanced Customization Possibilities

- Download, Print, or E-mail Search Results
- Exclusive Online Content

- Comprehensive Content

- User-Friendly Interface

To learn more about Choice Reviews Online, visit http://www.cro2info.org/

To sign up for free 60-day trial, visit http://www.cro2.org/

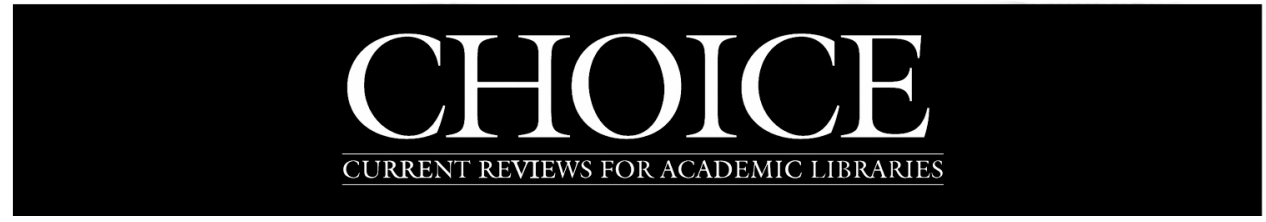

